The Midwest regional context complicates Asian American college student activism and social justice efforts so understanding these dynamics can equip higher education practitioners to better support these students.

\title{
Asian American College Student Activism and Social Justice in Midwest Contexts
}

Jeffrey Grim, Nue Lee, Samuel Museus, Vanessa Na, Marie P. Ting ${ }^{1}$

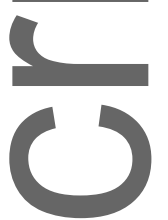

Systemic oppression shapes the experiences of Asian Americans. Globally, imperialism, colonialism, and struggles among major economic powers have led to systemic violence toward, and significant challenges for, Asian American communities (Aguirre \& Lio, 2008). Nationally, systemic racism—as well as other systems of oppression such as neoliberalism, poverty, and heteropatriarchy - continue to cause challenges for Asian America and the diverse communities within it. And, on college campuses, these forces have an impact on the everyday lives of Asian American faculty, staff, and students (Museus \& Park, 2012).

Many Asian Americans engage in efforts to resist systemic forms of oppression and advance equity through political activism. College and university leaders often view such resistance as a burden. However, political activism is a fundamental democratic process (Kezar, 2010; Slocum \& Rhoades, 2009. Therefore, we believe that institutions that claim and seek to cultivate students' skills to productively engage and lead in a democratic society should encourage student activism and understand how to eollaborate with activists to improve conditions on their campuses and in their surrounding communities. In this chapter, we provide insight into the factors that shape Asian American activism in the Midwest. In the following sections, we provide critical context necessary to understand the experiences of Asian American activists in postsecondary education in the Midwest region. Then, we present the findings of our study on the experiences of Asian American college

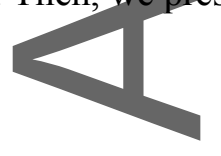

\footnotetext{
${ }^{1}$ All authors contributed equally to the production of this chapter, and names are listed in alphabetical order. This is the author manuscript accepted for publication and has undergone full peer review but has not been through the copyediting, typesetting, pagination and proofreading process, which may lead to differences between this version and the Version of Record. Please cite this article as doi: 10.1002/he.20321.

This article is protected by copyright. All rights reserved.
} 
student activists in the Midwest. We also offer a set of recommendations to support educators engaging Asian American college student activists in the Midwest region and beyond.

\section{Racial Context: Racism, Misconceptions, and Misleading Data}

Scholarship on how systemic racism and other forms of oppression and discrimination impact Asian American college students is sparse. However, research that does exist demonstrates that Asian American students often experience the effects of racial oppression in college (Kiang, 2002; Museus \& Truong, 2013; Vue, 2013). For example, this population experiences racial stereotypes, isolation, and hostility, as well as anxiety resulting from pressure to assimilate into majority cultures (Lewis, Chesler, \& Forman, 2000; Museus \& Park 2012; Vue, 2013). There is also evidence of the ways in which racism intersects with sexism to emasculate Asian American men and objectify Asian American women in college (Museus \& Truong, 2013).

One of the most salient mechanisms through which racism shapes Asian American experiences is the model minority myth, which portrays Asian Americans as passive or docile, successfully integrated into mainstream society, and academically exemplary relative to other racially minoritized groups (Museus, 2008). Although this myth may not seem harmful on the surface, it can result in the false narrative that Asian American students do not face challenges or need support. This assumption can lead to a lack of investment in support for Asian Americans, pressure for them to avoid seeking help, and pressure for them to major in science or math while foregoing other options that might lead some of them to be satisfied or find meaning in their education and profession (Choi \& Lahey, 2006; Museus \& Park; 2015).

In addition, researchers have noted that reliance on aggregate data can reinforce model minority misconceptions (Kiang, 2002; Museus, 2014). As an aggregate, Asian Americans appear to have high rates of educational attainment. However, many Asian American subgroups face significant disparities in college access, persistence, and success (Museus, 2013). In fact, some Asian American students come from some of the most under-resourced communities in the nation (Kiang, 2002; Ngo \& Lee, 2007; Um, 2003). 


\section{Asian American College Students and Activism}

While dominant narratives position Asian Americans as failing to possess leadership skills and engage politically (Lien, Conway, \& Wong, 2004), this community has a history of political activism in higher education and surrounding communities across the U.S. (Nguyen \& Gasman, 2017; Umemoto, 1989). Indeed, prominent Asian Americans have been heavily involved in some of the most significant national movements in history, such as the Civil Rights Movement. In addition, Asian Americans have spearheaded movements in support of immigration (Lowe, 1996; Vo, 1996), against unfair labor practices (Wong, 2000), against racial violence and discrimination (Kurashige, 2000; McClain, 1994), against residential racial segregation (Massey \& Denton, 1993; Park, 1996), for educational equity)(Umemoto, 1989), and for redress for Japanese Americans forced into internment camps during World War II (Maki, Kitano, \& Berthold, 1999). Thus, despite stereotypes of Asian American complacency, they have historically organized politically, socially, and economically to fight for social justice in the U.S.

Within higher education, Asian American activism frequently emerges in response to systemic oppression manifesting on college campuses and in surrounding communities. For example, in the 1960s and 1970s, in response to higher education's failure to meet the needs of minoritized communities, Asian American students joined their peers to fight for more culturally relevant curricula and increased racial equity (Ryoo \& Ho, 2013; Umemoto, 1989). Since these student movements, Asian American students across the nation have advocated for and created ethnic subcultures (e.g., Asian American studies and Asian American student organizations) that provide mechanisms for these students to increase awareness of their realities, support their peers on campus, and give baek to their communities (Chhuon \& Hudley, 2008; Kiang, 2002; Museus, 2008; Museus, Shiroma, \& Dizon, 2016; Vue, 2013). These identity-based subcultures often provide space for the exploration of Asian American history, culture, and community, thereby cultivating leaders and activists (Lin, 2018; Suyemoto, Day, \& Schwartz, 2015). For example, Lin (2018) conducted a mixed-method study of Asian American college students and established that grassroots political student organizations led to increased political consciousness among these students and led them to advocate for educational and social justice causes. Because Asian American historical narratives and 
voices are often ignored in social and political conversations, they must often create their own counterspaces to learn about and engage in social justice work.

\section{Midwest Contexts and Asian American Activism}

Asian American communities vary across geographic contexts within the U.S. (Lee, 2009). For example, according to the last national census in 2010, almost half (46\%) of Asian Americans in the U.S. resided in the West, followed by $22 \%$ in the South, $20 \%$ in the East, and $12 \%$ in the Midwest (U.S. Census Bureau, 2012). These statistics suggest that Asian American communities in the Midwest are smalter than in other regions, which might lead to them facing unique challenges as a result of these low levels of representation.

At the same time, there are sizable Asian American communities in the Midwest. For example, oyer 2 million Asian Americans lived in the Midwest in 2010, and Illinois has the sixth largest Asian American population of all U.S. states (U.S. Census Bureau, 2012). With regard to Southeast Asian Americans (Cambodian, Hmong, Lao, and Vietnamese Americans) - the refugee groups that face some of the most significant barriers to education — several Midwest states are among those with the largest communities (Southeast Asian Resource Action Center, 2011). In addition. Between 2000 and 2010, the Asian American community grew most rapidly in the South (69\%), while their growth was second fastest in the Midwest (48\%). In sum, these data indicate that the Asian American community is growing faster in the Midwest than in most areas of the country, Asian Americans in the Midwest might continue to play an increasingly salient role in defining Asian America moving forward, and it is therefore important to understand their experiences, needs, and stories within this region's context.

There is some indication that geographic context in general and the Midwest context in particular might play a role in shaping the experiences and perspectives of Asian American college students. For example, scholars have argued that place, space, and geographic location influence how race is experienced, understood, and expressed (Berry \& Henderson, 2002). Researchers have also documented the ways in which different geographic origins, along with other contextual factors (e.g., family and mentors) influence how Asian Americans make sense of their racial identity (Chan, 2017). This research suggests that the Midwest is dominated by Black-White racial discourse, a lack of Asian 
American representation, and smaller Asian American communities that lead to limited educational opportunities to learn about Asian American histories and cultures. Yet, little is known about whether and how such regional factors shape Asian American activism taking place within the Midwest.

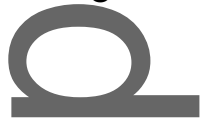

\section{Study and Methods}

Qualitative methods were utilized to execute the current investigation because they facilitate the indepth examination of processes and phenomena through detailed information (Creswell, 1998). In addition, qualitative methods were deemed ideal for answering our overarching research question: How does the Midwest regional context shape Asian American social justice activism? To answer this question, we conducted qualitative focus group interviews with administrators and staff working with Asian American student organizations in the Midwest.

\section{Participant Recruitment}

To recruit the sample for this study, we utilized purposeful sampling to achieve intensity (i.e., information richness) and variation (i.e., diversity in social identity, position, and institutional type). Specifically, we sought administrators who work with Asian American student organizations because they were deemed most likely to understand the systems within which Asian American student leaders and activists are embedded.

A letter soliciting recommendations of participants for the study was sent to senior student affairs administrators at institutions of higher education affiliated with the Midwest Asian American Student Union (MAASU). MAASU is a regional annual student-run conference that is held in various locations across the Midwest region and focuses on understanding Asian American issues, Asian American leadership development, strengthening Asian American resistance to all forms of oppression, and uniting and serving Asian American communities. We utilized responses from senior administrators who were contacted to develop an initial list of potential participants. These potential participants were invited to apply to participate in the study by providing basic demographic data, describing their experiences with Asian American student leaders, and submitting their curriculum vitae. Participants who had significant experience working with Asian American organizations and diverse social identities (race, ethnicity, gender) and position levels (entry, mid, and executive level) were selected for participation. The final sample included 13 participants. 


\section{Data Collection and Analysis}

The participants were split into three focus groups, which were facilitated by a member of the research team and lasted approximately three hours, including breaks. Participants were asked a series of questions about contextual factors that influence Asian American students' experiences and involvement in social justice activism. Another member of the research team took notes and recorded observations. The interviews were also audio-recorded and professionally transcribed.

Once the focus group interviews were transcribed, we coded data in Dedoose- - a web-based qualitative analysis software program. We used initial, axial, and focused coding to analyze the data (Charmaz, 2010; Glaser \& Strauss, 1967). In this first phase of initial coding, we read transcripts with an openness to all possible thematic and theoretical possibilities that may be generated. We then used axial coding to build upon the initial codes and identify their attributes (e.g., properties or elements). Finally, weutilized focused coding to determine the most salient themes in the data and relationships among them.

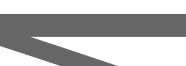

\section{Findings}

Our analysis generated important insights into how the Midwest context shapes Asian American student activism. In this section, we provide an overview of these themes. Before doing so, however, it is important to underscore that participants supported Asian American students engaging in many forms of activism, including supporting national movements (e.g., \#BlackLivesMatter and the movement to protect undocumented students), organizing events (e.g., social justice conferences), facilitating dialogues across communities of color, and responding to discriminatory incidents that sparked tension in their campus climates. Thus, Asian Americans in the Midwest were fighting for social justiee in many ways. These efforts, however, were complicated by the realities of the Midwest context, to which we now turn.

\section{Exclusion from Diversity and Equity Discourse}

Given the relatively small size of Asian American communities and low levels of representation in most areas of the Midwest, it is not surprising that Asian Americans in this region often experience exclusion. However, participants also described ways in which diversity and equity conversations specifically excluded Asian American voices, concerns, and issues in the Midwest. One participant 
stated, "In the Midwest, Asian Americans don't have a seat at the table. They are not invited to conversations about diversity. They're not thought of in diversity initiatives." They noted that these conversations typically focused on White and underrepresented students, and the term "underrepresented" was often used synonymously with Black students or Black and Latinx students. Participants underscored the importance of addressing challenges faced by these communities, and problems with ignoring Asian Americans_-as well as Native Americans and Pacific Islandersaltogether. As a result of these dynamics, Asian Americans in the Midwest struggled to balance their support for movements to advocate for other communities (e.g., \#BlackLivesMatter) and fighting for their own voiees and issues to be acknowledged.

Participants also noted that the dismissal of Asian Americans from these conversations was fueled by the model minority stereotype, reliance on simplistic aggregate data, and myopic focus on retention rates in determining who should be included in conversations about diversity. Specifically, they described how campus leaders often emphasized lower retention and graduation rates among Black and Latinx students as a rationale for ignoring Asian Americans. They underscored that such assumptions were problematic, given that Asian Americans faced significant struggles as well. They also highlighted the problem with their institutions' overreliance on aggregate data, because it masked significant disparities within Asian American communities and reinforced model minority assumptions. These realties often led Asian American students to expend excessive amounts of energy explaining and justifying why they should be included in diversity and equity conversations.

\section{Limited Structures to Support Activism}

Participants also discussed the reality that there were limited structures to support the training and work of Asian American social justice activists in the Midwest. They highlighted the reality that histories of Asian American activism and engagement in social justice work exist in the Midwest, citing Asian American icons from the civil rights movement and the ways in which Asian American movements led to the creation of Asian American studies programs and departments on Midwestern college and university campuses. Asian American studies was also noted as a critical source of constructing Asian American histories and sharing knowledge of Asian American communities in the Midwest and beyond. 
Yet, interview participants noted that these stories were untold and unheard in most spaces in the Midwest. They reported that students who were not from major cities had limited exposure to stories of activism in general and Asian American activism in particular. As a result, they perceived many Asian American students in the Midwest to be unable to see themselves as social justice activists. Participants discussed the need for faculty and staff to spend significant time and energy with Asian American students to build a foundation of knowledge about the social and political issues that affect their communities and the importance of addressing them, before cultivating their skills to engage in social justice leadership and advocacy work.

\section{Cooling Effeet of "Midwest Niceness"}

Participants discussed the ways that Midwest culture was characterized by "Midwest niceness," which was described as being nice to each other and avoiding conflict and disruptive behavior. They perceived this Midwest nice culture as making Asian American and other college students on their campuses more inclined to participate in social organizations, activities, and events than to gravitate toward social justice work.

Our interviewees also suggested that this Midwest niceness compounded other pressures for Asian American students to avoid engaging in social justice activism. For example, they emphasized that stereotypes of Asian Americans as passive, docile, and assimilative model minorities reinforced messages that they should not engage in disruptive activist behavior. In addition, they noted that many families of Asian American students with whom they worked did not immediately understand the value or benefits of students engaging in this work. In response, they highlighted the importance of educating students about how the model minority stereotype might influence their lives and the lives of other people of color and informing Asian American families about the benefits of being involve in social and political causes.

\section{Pull Away from the Midwest}

Finally, participants discussed the ways in which Asian American students in the Midwest experienced a pull away from the region. Specifically, they noted that Asian American students often romanticized the volume of historical and contemporary forms of activism on the west and east 
coasts. They attributed this romanticization, at least in part, to students' limited knowledge of the racial challenges and struggles that existed in other regions of the U.S.

Participants also noted that many Asian American student activists with whom they worked expressed a desire to leave the Midwest after finishing college. These students believed they would learn much more about activism and develop increased capacity to make change on the coasts.

Participants believed that these perceptions were inflated, given the significant potential to make a difference in the Midwest. For example, one participant underscored the reality that many swing states that determined the outcome of the last presidential election were located in the region. As a result, they underscored the need for more documented stories and models of activism and progress taking place in the Midwest, so that Asian American students can see their potential impact on the system. Although participants discussed this phenomenon primarily as a pull away from the region, the exclusion of Asian Americans from diversity and equity conversations, limited representation and structures to support their activism, and Midwest niceness that hinder activist behavior also likely fueled these desires to leave.

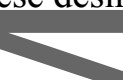

Our analysis has several implications for administrators and educators working with Asian American activists in the Midwest and beyond. They include the following:

- Ensure Asian Americans are part of the larger diversity and equity agenda. Institutions of higher education can and should engage Asian American student leaders in campus diversity and equity conversations to ensure that their needs and interests are included in their institutions' larger diversity and equity agenda. The engagement of Asian American college students in these conversations is necessary for campuses to provide them with opportunities to develop civic responsibility and commitments, cultivate their capacities to engage in political processes, and foster greater understanding between them and other communities on their respective campuses.

- Create data systems to facilitate more accurate understandings of Asian American communities. Institutions of higher education must create and maintain systems to generate 
data that illuminate the diversity and disparities that exist within the Asian American community. Colleges and universities should implement policies and practices to normalize disaggregation of institutional data across ethnicities and socioeconomic classes to equip campus community members to challenge pervasive misconceptions about Asian Americans.

- Encourage greater understanding of regional differences and similarities. Educators working directly with Asian American students should provide them with opportunities to engage in hands-on advocacy experiences in different areas of the Midwest and beyond. For example, institutions in rural areas of the Midwest can collaborate with Asian American community organizations in Chicago, Minneapolis, and other major cities to learn about and engage in activism with these organizations. Such opportunities can help students develop a more complex understanding of activism across regional contexts and help them find greater value in activism within the Midwest region. Asian American student leaders should also be encouraged to attend regional and national meetings that focus on Asian American issues and social justice, such as the Midwest Asian American Student Union (MAASU) and the Association of Asian American Studies (AAAS) conferences, where they have an opportunity to interact with Asian American community leaders across the nation and learn about common and different struggles and successes across regions.

- Support, expand, and sustain Asian American studies programs and curricula. Asian American studies programs provide spaces for Asian Americans to learn about their communities and how to advocate for them. Asian American students should be encouraged to take courses in Asian American studies to gain a richer understanding of their comm communities' histories and contemporary issues. Equally important, however, is the fact that faculty across disciplines and fields— such as history and sociology—can offer culturally relevant curricula that engages the histories, struggles, and stories of Asian American communities into their courses. It is especially urgent for faculty in the Midwest to find ways to highlight the histories of Asian American communities in the Midwest to expose students to the many ways that Asian American social and political action takes place within the 
region.

- Encourage engagement in controversy with courage. Asian American student activists struggle with their "place" in conversations about current social justice issues such as immigration and Black Lives Matters. For example, Asian American students may struggle with how to balance their support of Black student activism with fighting for recognition of the history of racism against Asian Americans. And, while such conversations can be difficult, activism requires some level of risk (Cabrera, Matias, \& Montoya, 2017), and advocating for social justice requires engaging in controversy with courage (Museus, Sanchez-Parkinson, Calhoun, Lee, \& Ting, 2018). Institutions should consider how to equip and support Asian American and other students to engage in these conversations within and outside of their communities. Campuses should also create more spaces to engage in dialogue about critical social and political issues across communities. If institutions of higher education can provide tools for students to navigate these complex issues, it will only strengthen students' abilities to build coalitions within and across racial and ethnic groups, which are critical in efforts to combat systemic oppression in our society and around the world.

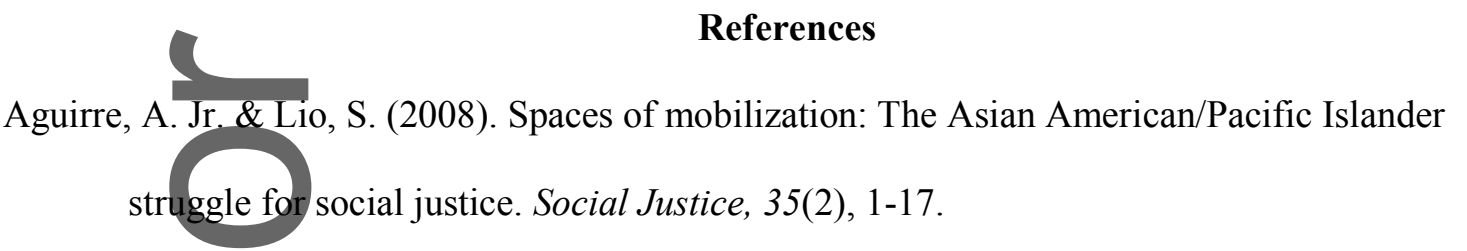

Berry, K. A. \& Henderson, M. L. (2002). Geographical identities of ethnic America: race, space, and place. Reno, NV: University of Nevada Press.

Cabrera, N.-L., Matias, C. E., \& Montoya, R. (2017). Activism or slacktivism? The potential and pitfalls of social media in contemporary student activism. Journal of Diversity in Higher Education, 10(4), 400-415.

Chan, J. (2017). "Being Asian American is a lot different here": Influences of geography on racial identity. Journal of College Student Development, 58(7), 1001-1017.

Charmaz, K. (2010). Constructing grounded theory (Second Edition). Thousand Oaks, CA: SAGE Publications. 
Chhuon, V. \& Hudley, C. (2008). “Factors Supporting Cambodian American Students' Successful Adjustment into the University." Journal of College Student Development 49 (1): 15-30

Cho, S. K. (2003). Converging stereotypes in racialized sexual harassment: Where the model minority meets Suzie Wong. In A. K. Wing (Ed.), Critical race feminism: A reader (pp. 349-356). New York, NY: New York University Press.

Choi, Y.; \& Lahey,B. B. (2006). Testing the model minority stereotype: Youth behaviors across radial and ethnic groups. Social Service Review, 80(3), 419-452.

Creswell, J W. (1998). Qualitative inquiry and research design: Choosing among five traditions.

Thousand Oaks, CA : Sage Publications, Inc.

Dhingra, P. 2003. "Being American Between Black and White: Second-Generation Asian American Professionals' Racial Identities.” Journal of Asian American Studies 6(2), 117-147.

Geron, K., de la Cruz, E., Saito, L. T., \& Singh, J. (2001). Asian Pacific-Americans' social movements and interest groups. PS, Political Science \& Politics, 34(3), 618-624.

Glaser, B. G., \& Strauss, A. L. (1967). The discovery of grounded theory; strategies for qualitative research. Chicago, IL: Aldine Publications, Co.

Guardia, J.R. \& Evans, N.J. (2008). Factors influencing the ethnic identity development of Latino fraternity members at Hispanic serving institutions. Journal of College Student Development, $49,163-181$.

Kezar, A. (2010). Faculty and staff partnering with student activists: Unexplored terrains of interaction and development. Journal of College Student Development, 51, 451-480.

Kiang, P. N. (2002). Stories and Structures of Persistence: Ethnographic learning through research and practice in Asian American studies. In Y. Zou \& H. T. Trueba (Eds.), Advances in ethnographic research: From our theoretical and methodological roots to post-modern critical ethnography (pp. 223-255). Lanham, MD: Rowman \& Littlefield.

Kurashige, S. (2000). Pan-Ethnicity and community organizing: Asian Americans united campaign against anti-Asian violence. Journal of Asian American Studies, 3, 163-190.

Kwon, S. A. (2013). The politics and institutionalization of panethnic identity. Journal of Asian American Studies, 16(2), 137-157. 
Lee, E. (2009). Asian American studies in the Midwest: New questions, approaches, and communities. Journal of Asian American Studies, 12(3), 247-273.

Lewis, A. E., Chesler, M., \& Forman, T. A. (2000). The impact of "colorblind" ideologies on students of color group relations at a predominantly White university. Journal of Negro Education,

$40(3), 56-76$.

Lien, P., Conway, M. and Wong, J. (2004). The politics of Asian Americans: Diversity and community. New York, NY: Routledge.

Lin, M. (2018) From alienated activists: Expressions and formation of group consciousness among Asian American young adults. Journal of Ethnic and Migration Studies, 1-20.

Lowe, L. (1996). Immigrant acts: On Asian American cultural politics. Durham, NC: Duke

University Press.

Maki, M. T., Kitano, H. H. L., \& Berthold, S. M. (1999). Achieving the impossible dream: How Japanese Americans obtained redress. Urbana, IL: University of Illinois Press.

Massey, D. S. \& Denton, N. A. (1993). American apartheid. Cambridge, MA: Harvard University Press.

McClain, C.J.(1994). In search of equality: The Chinese struggle against discrimination in nineteenth century America. Berkeley, CA: University of California Press.

Merriam, S. B. \& Tisdell, E.J. (2015). Qualitative research: A guide to design and implementation. (4th ed). San Francisco, CA: Jossey-Bass.

Museus, S. D. (2008). The model minority and the inferior minority myths: Understanding stereotypes and their implications for student involvement. About Campus, 13(3), 2-8.

Museus, S.D. (2013). Asian Americans and Pacific Islanders: A national portrait of growth, diversity, and inequality. In S. D. Museus, D. C. Maramba, \& R. T. Teranishi (Eds.), The misrepresented minority: New insights on Asian Americans and Pacific Islanders, and their
implications for higher education. Sterling, VA: Stylus.

Museus, S. D. (2014). The Culturally Engaging Campus Environments (CECE) Model: A new theory of college success among racially diverse student populations. In M. B. Paulsen (Ed.), Higher Education: Handbook of Theory and Research (pp. 189-227). New York: Springer.

This article is protected by copyright. All rights reserved. 
Museus, S. D., \& Kiang, P. N. (2009). Deconstructing the model minority myth and how it contributes to the invisible minority reality in higher education research. New Directions for Institutional Research, 142, 5-15.

Museus, S. D., Lee, N., Calhoun, K., Sanchez-Parkinson, L., \& Ting, M. (2017). The Social Action, Leadership and Transformation (SALT) model. Bloomington, IN: The National Institute for Transformation and Equity.

Museus, S.M. \& Park, J.J. (2015). The continuing significance of racism in the lives of Asian American college students. Journal of College Student Development, 56(6), 551-569.

Museus, S. D., Museus, S. D., Sanchez-Parkinson, L., Calhoun, K. A., Lee, N, \& Ting, M. (2018).

The Social Action, Leadership, and Transformation (SALT) Model. Ann Arbor, MI: National Center for Institutional Diversity

Museus, S.D. \& Shiroma, K. \& Dizon, J.P. (2016). Cultural Community Connections and College Success: An Examination of Southeast Asian American College Students. Journal of College Student Development 57(5), 485-502.

Museus, S. D. \& Truong, K. A. (2013). Racism and sexism in cyberspace: Engaging stereotypes of Asian American women and men to facilitate student learning and development. About Campus, 18(4), 14-21.

Museus, S. D., \& Yi, V. (2015). Rethinking student involvement and engagement: Cultivating culturally relevant and responsive contexts for campus participation. In D. Mitchell Jr., K. M. Soria, E. A. Daniele, \& J. A. Gipson (Eds.), Student involvement and academic outcomes: Implications for diverse college student populations, (pp. 11-24) New York, NY: Peter Lang. Ngo, B., \& Lee, S. J. (2007). Complicating the image of model minority success: A review of Southeast Asian American education. Review of Educational Research, 77, 415-453.

Nguyen, T-H \& Gasman, M. (2017). Activism, identity, and service: The influence of the Asian American movement on the educational experiences of college students. Journal of History of Education, 44(3) 339-354.

O'Brien, E. (2008). The racial middle: Latinos and Asian Americans living beyond the racial divide. New York City: NYU Press. 
Park, E. J. W. (1996). “Our L.A.?” Korean Americans in Los Angeles after the civil unrest. In M J. Dear, H. E. Shockman, \& G. Hise (Eds.) Rethinking Los Angeles (pp. 153-168). Thousand Oaks, CA: Sage.

Park, P. (2002). Activism and the consciousness of difference. In Kumashiro, K. K. (2004). Restoried Selves: Autobiographies of Queer Asian/Pacific American Activists. (pp. 93-99). New York, NY: Harrington Park Press.

Patton, M. Q. (2001). Qualitative research and evaluation methods. (3rd ed.). Thousand Oaks, CA: SAGE Publications, Inc.

Patton, L. D., Renn, K. A., Guido, F. M., \& Quaye, S. J. (2016). Student development in college:

Theory, research, and practice. San Francisco, CA: Jossey-Bass.

Pew Research Center (2013). The rise of Asian Americans. Washington, DC: Pew Research Center.

Renn, K. A. \& Arnold, K. D. (2003). Reconceptualizing research on peer culture. Journal of Higher Education, 74, 261-291.

Ryoo, J. J., \& Ho, R. (2013). Living the legacy of ' 68 : The perspectives and experiences of Asian American student activists. In S. D. Museus, D. C. Maramba, \& R. T. Teranishi (Eds.), The misrepresented minority: New insights on Asian Americans and Pacific Islanders, and the implications for higher education (pp. 213-226). Sterling, VA: Stylus.

Slocum, J., \& Rhoads, R. A. (2009). Faculty and student engagement in the Argentine grassroots rebellion: Toward a democratic and emancipatory vision of the university. Higher Education,

Southeast Asian Resource Action Center (2011). Southeast Asian Americans at a glance: Statistics on Southeast Asians adapted from the American Community Survey. Washington, DC: Author.

Suyemoto, K. L., Day, S. C., \& Schwrtz, S. (2015). Exploring effects of social justice youth programming on raical and ethnic identities and activism for Asian American youth. Asian American Journal of Psychology, 6(2), 125=135.

Um, K. (2003). A dream denied: Educational experiences of Southeast Asian American youth. Washington, DC: Southeast Asia Resource Action Center. 
Umemoto, K. (1989). “On strike!” San Francisco State College strike 1968-1969: The role of Asian American students. Amerasia Journal, 15(1), 3-41.

U.S. Census Bureau (2012). The Asian population: 2010. Washington, DC: Author.

Vaughn, S., Schumm, J. S., \& Sinagub, J. M. (1996). Focus group interviews in education and psychology. Thousand Oaks, CA: Sage Publications, Inc.

Vo, L. T. (1996). Asian immigrants, Asian Americans, and the politics of economic mobilization in San Diego. Amerasia Journal, 24(2), page numbers

Vue, R. (2013) Searching for self, discovering community: An examination of the experiences of Hmong American college students. In S. D. Museus, D. C. Maramba, \& R. T. Teranishi (Eds.), The misrepresented minority: New insights on Asian Americans and Pacific Islanders, and their implications for higher education (pp. 214-234). Sterling, VA: Stylus.

Wong, K. (2000). Building an Asian Pacific labor movement. In F. Ho, C. Antonio, D. Fujino, \& S. Yip(Eds.), Legacy to liberation: Politics and culture of revolutionary Asian Pacific America (pp. 89-98). San Francisco, CA: Big Red Media.

Wu, F. H. (1995), Neither Black nor White: Asian Americans and affirmative action. Boston College Third World Law Journal, 15, 225-284.

\footnotetext{
Jeffrey Grim is a doctoral candidate at the Center for Study of Higher and Postsecondary Education at the University of Michigan, Ann Arbor.
}

Nue Lee is a graduate of the University of Minnesota, Twin Cities.

Samuel D. Museus is professor in the Department of Education Studies at University of California, San Diego.

Vanessa Na is a doctoral student in the Department of Education Studies at the University of California, San Diego.

Marie P. Ting is associate director at the National Center for Institutional Diversity at the University of Michigan, Ann Arbor. 